\title{
Intellectual Capital as a Performance Measurement Model in Small Enterprises of Batik Industries in Central Java (Study on Batik SMEs in Laweyan Solo)
}

\author{
Handoyo D. Waluyo ${ }^{1}$, Wahyu Hidayat ${ }^{2}$, Reni Shinta Dewi ${ }^{3}$ \\ \{handoyodw@yahoo.co.id ${ }^{1}$,wahju.hidajat@yahoo.com ${ }^{2}$, renishinta@yahoo.co.id ${ }^{3}$ \} \\ Universitas Diponegoro, Indonesia ${ }^{1,2,3}$
}

\begin{abstract}
Intellectual capital constitutes intangible assets that will add the value of the company to achieve a competitive advantage. The purpose of this study is the development of intellectual capital as a performance measurement model on Small Enterprises of the Batik industries in Central Java. A conceptual model was developed to explain the effect of intellectual capital on performance through innovation. The scope of intellectual capital consists of human capital, social capital, structural capital, relational capital, technology capital and spiritual capital. The study conducted at Kampoeng Batik Laweyan. The sample is 50 SME's and data analyzed using the Statistical Package for Social Sciences (SPSS). The results show that intellectual capital is a significant effect on performance through innovation. This finding is in line with $\mathrm{KBV}$, which explains that intellectual capital as an intangible capital that can create value and will leads to organizational performance. Limitations, the result of this study couldn't be generalized. For further research, necessary to expand the coverage.
\end{abstract}

Keywords: Intellectual Capital, Innovation, Performance.

\section{Introduction}

The transformation of the industrial era into the information age requires SMEs to manage and explore a knowledge-based economy [1][2]. In a knowledge-based economy, intangible assets are the most important factor in performance development [3], especially for SMEs [1][3]. The approach used to measure an intangible asset is by using the concept of intellectual capital and for SME's, intellectual capital is regarded as a source that has a competitive advantage for a firm.

Intangible asset management through knowledge has been utilized by large companies because it is proven that these resources can create value and competitive advantage. For Small and Medium Enterprises (SMEs), the concept of intangible asset starts getting attention, especially in developing countries due to its great effect on organizational success [5]. Therefore, the main contribution is to explore the model of intellectual capital developed by Khalique [5] especially in the Batik industry in Central Java, Indonesia in order to increase innovation and organizational performance. 


\section{Theoretical Framework}

$\mathrm{KBV}$ emphasizes that the main reason for companies to have a competitive advantage is the creation and application of knowledge [7]. Knowledge in business is manifested as intellectual capital [8]. Intellectual capital is an intangible resource that includes knowledge and information that can be used by organizations to improve organizational performance [5].

The creation of new knowledge generated through the process of learning from internal and external sources that can help a firm to achieve superior performance because the benefits of creating new knowledge are responsive to customers and the ability to adapt to changes and uncertain environments [9]. In this study, the dimensions of the intellectual capital built in line with the research conducted by [5], namely human capital, social capital, structural capital, relational capital, technological capital, and spiritual capital. For this reason, the hypotheses are:

Hypothesis 1a: Human capital effect on organizational performance

Hypothesis 1b: Social capital effect on organizational performance

Hypothesis 1c: Structural capital effect on organizational performance

Hypothesis 1d: Relational capital effect on organizational performance

Hypothesis 1e: Technology capital effect on organizational performance

Hypothesis 1f: Spiritual capital effect on organizational performance

Knowledge-based views (KBV) explain that intellectual capital is the first asset that must be transferred into innovation in order to create competitive advantage and improve organizational performance. Delgado-Verde et al, [10] stated that knowledge capital is the main key of an organization and is responsible for creating innovation. Intangible assets are an important factor in creating competitiveness especially for medium-sized companies, this shows that the ability of organizations to innovate is closely related to intellectual capital, or the ability to utilize knowledge resources [10]. The hypothesis was:

Hypothesis 2a: Human capital effect on innovation

Hypothesis 2b: Social capital effect on innovation

Hypothesis 2c: Structural capital effect on innovation

Hypothesis 2d: Relational capital effect on innovation

Hypothesis 2e: Technology capital effect on innovation

Hypothesis 2f: Spiritual capital effect on innovation

Innovation is very important because it does not only increase the welfare of the firm but also to encourage economic growth [11]. Without innovation, firms tend to be less competitive and less attractive, both to customers and members of the firm, and overall it tends to fail. Innovation and technology are the main factors lead to performance improvement [12]. The hypothesis was:

Hypothesis 3: Innovation drives organizational performance improvement

Hypothesis 4: Innovation is a mediating variable between intellectual capital and organizational performance

\section{Methods}

The type of research was survey carried out cross-sectionally for two months. The research was carried out in the biggest batik industry center in Central Java, Indonesia (Solo). Multistage sampling technique is used for population determination. First, the batik industry 
which has annual sales of between IDR 300,000,000-2,500,000,000 (US \$ 21060.79178606.25). Second, the batik industry had been running for 3 (three) years [13]. 50 SMEs were determined as samples, we found that the sample structure matched the goodness of fit test [14].

Data were analyzed using Statistical Package for Social Sciences (SPSS) for statistical analysis. Hierarchical regression analysis is used to test the effect of independent variables on the dependent variable and to test the effect of the innovation moderation variable on the relationship of intellectual capital and organizational performance.

\subsection{Measures}

a) Intellectual Capital. Measures of intellectual capital using a Likert scale of 5 points adopting Khalique et al, [5], namely human capital, social capital, structural capital, relational capital, technological capital, and spiritual capital, as many as 31 items. Validity test $(>.56)$ and reliability $(0.853)$ showed the valid and reliable result.

b) Innovation. Likert Scale of five points was used to measure 5 question items, adopted from Kalkan et al. (2014). It consisted of 5 factors, they were product, service, method, marketing and procedure innovation. Validity test $(>.60)$ and reliability $(0.803)$ showed valid and reliable result.

c) Performance. Performance is measured using Likert scale of 5 points, adopting Jardon and Martos [15], using 4 factors namely market share, profitability, productivity, and the number of workers. The test result towards 4 items showed a valid result $(>.54)$ and reliable $(0.825)$.

\section{Result and Discussion}

Demographic information shows that the majority of SME owners are male (78\%), aged between $40-50$ years (48\%). In terms of education, most of the owners graduated from high school (50,5\%). Most of the Batik industry had been running 10-20 years (54\%).

The validity test results show that all items have a value $>.57$ and reliability $>.770$. Factor analysis was performed using exploratory factor analysis. According to Hair [16] the loading threshold factor based on the size of the sample is $0.55 ; 0.6 ; 0.65 ; 0,7 ; 0,75$ for sample size $100 ; 85 ; 70 ; 60$ and 50 .

The accepted loading level based on the sample size is 0.55 [16]. In this study, exploratory factor analysis was carried out on 11 items of human capital variable, 6 items of social capital, 3 items of structural capital, 4 items of relational capital, 3 items of technology capital, 4 items of spiritual capital, 5 items of innovation and 4 performance items. The results show that all constructs had values above factor loading thresholds $(>0,55)$. The table 1 shows the results of the exploratory factor analysis.

Table 1. Exploratory factor analysis.

\begin{tabular}{lcc}
\hline Variable & KMO & $\boldsymbol{\chi}^{\mathbf{2}}(\boldsymbol{p}=\mathbf{0 , 0 1})$ \\
\hline Human Capital (11) & 0,813 & 264,569 \\
Competence (4) & & \\
Attitude (3) & & \\
Intellectual Capability (4) & & \\
\hline Social Capital (6) & 0,735 & 142,981
\end{tabular}




\begin{tabular}{lcc} 
Culture (6) & & \\
\hline Structural Capital (3) & 0,689 & 69,020 \\
$\begin{array}{l}\text { Procedure (2) } \\
\text { Policy (1) }\end{array}$ & & \\
\hline Relational Capital (4) & 0,657 & 63,178 \\
Network (4) & 0,598 & 58,562 \\
\hline Technological Capital (3) & 0,613 & 60,345 \\
\hline Spiritual Capital (4) & & \\
$\begin{array}{l}\text { Religious (2) } \\
\text { Ethic Values (2) }\end{array}$ & 0,621 & 242,546 \\
\hline Innovation (5) & 0,712 & 102,350 \\
\hline Performance (4) & & \\
\hline
\end{tabular}

In this study, three models were developed using the three stages of Baron and Kenny [17], to examine the mediating effects of innovation, using hierarchical regression analysis. In the first step, there are two stages, the first stage is the effect of intellectual capital on performance (stage 1). On the second stage, intellectual capital is tested with innovation (stage 2). Step 2, examines the effect of innovation on performance. Step 3 is developed to examine the mediating effects of innovation towards intellectual capital and performance.

Table 2. Hierarchical regression analysis.

\begin{tabular}{|c|c|c|c|c|}
\hline Model & $\beta$ & $\mathbf{t}$ & $\rho$ & Summary \\
\hline \multicolumn{5}{|l|}{ Step 1} \\
\hline \multicolumn{5}{|l|}{ Stage 1} \\
\hline Human Capital & $0,646^{* *}$ & 3,247 & 0,016 & $\mathrm{R} 0,462 \mathrm{R}^{2} 0,213$ \\
\hline Social Capital & $0,608 * *$ & 2,333 & 0,024 & F $4,797 \rho<0,034$ \\
\hline Structural Capital & $0,547 * *$ & 2,292 & 0,027 & Dependent: Performance \\
\hline Technology Capital & 0,184 & 0,929 & 0,358 & \\
\hline Relational Capital & 0,132 & 0,715 & 0,479 & \\
\hline Spiritual Capital & $-0,126$ & $-0,762$ & 0,450 & \\
\hline \multicolumn{5}{|l|}{ Stage 2} \\
\hline Human Capital & $0,668 * *$ & 3,508 & 0,000 & $\mathrm{R} 0,764 \mathrm{R}^{2} 0,584$ \\
\hline Social Capital & $0,664 * *$ & 3,501 & 0,001 & F $10,062 \rho<0,000$ \\
\hline Structural Capital & $-0,372 * *$ & $-2,141$ & 0,038 & Dependent: Innovation \\
\hline Technology Capital & $0,504 * *$ & 3,496 & 0,001 & \\
\hline Relational Capital & 0,025 & 0,185 & 0,854 & \\
\hline Spiritual Capital & $-0,061$ & $-0,508$ & 0,614 & \\
\hline \multicolumn{5}{|l|}{ Step 2} \\
\hline Innovation & $.455^{* *}$ & 3,944 &, 000 & R $0,495 \mathrm{R}^{2}, 245$ \\
\hline & & & & F $15,553 \rho<0,000$ \\
\hline & & & & Dependent: Performance \\
\hline \multicolumn{5}{|r|}{ 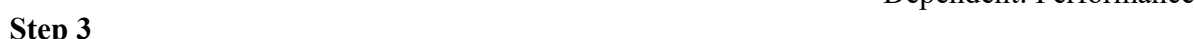 } \\
\hline Human Capital & $-0,016$ & $-0,088$ & 0,930 & R $0,542 \mathrm{R}^{2} 0,294$ \\
\hline Social Capital & 0,316 & 1,116 & 0,271 & $F 2,500 \rho<0,034$ \\
\hline Structural Capital & 0,384 & $-1,593$ & 0,119 & Dependent: Performance \\
\hline Technology Capital & 0,038 & $-0,175$ & 0,862 & \\
\hline Relational Capital & 0,121 & 0,683 & 0,498 & \\
\hline Spiritual Capital & 0,099 & $-0,623$ & 0,536 & \\
\hline Innovation & $0,440 * *$ & 3,219 & 0,034 & \\
\hline
\end{tabular}


The results showed that the hypotheses $1 \mathrm{a}, 1 \mathrm{~b}$ and $1 \mathrm{c}$ were accepted. Human capital $(\beta=$ $0,281, \mathrm{t}=2,026, \rho<0,05)$, Social capital $(\beta=0,281, \mathrm{t}=2,026, \rho<0,05)$ and structural capital $(\beta=0,281, t=2,026, \rho<0,05)$ has a significant positive effect on performance. While H1d, $\mathrm{H} 1 \mathrm{e}$ dan H1f were found to be insignificant. This finding is different from the Khalique study (2015), wherein social capital, structural capital, technology capital, relational capital, and spiritual capital affect organizational performance. Meanwhile, human capital was found to be insignificant.

These findings in table 3 , show that human capital, social capital, structural capital and technological capital significantly affect innovation. This finding proved the support of H.2a, $2 \mathrm{~b}, 2 \mathrm{c}$, and $2 \mathrm{~d}$. This finding in line with Delgado-Verde et al [10] which explains that intellectual capital is an important factor for creating innovation.

Hypothesis H3, testing the influences between innovation toward performance found supporting evidence toward H3 $(\beta=0.455, \mathrm{t}=3.944, \rho<0.00)$, meaning that increasing innovation will also improve the performance. This study supports Supriyadi [12], which states that innovation is the key to improving performance

The mediating effect found evidence of support for the hypothesis 4 . The analysis showed that intellectual capital insignificantly influenced on performance, but innovation had a significant effect on performance $(\beta=0,440, t=3,219, \rho<0,034)$, this finding shows that innovation becomes a full mediating variable between intellectual capital toward performance. This finding in line with Delgado-Verde et al, [10], Supriyadi [12] and Khalique [5]. Intellectual capital is the main capital that encouraged innovation and leads to performance improvement

\section{Conclusion}

The empirical results showed that intellectual capital was a determinant factor for innovation and leads to performance improvement. This finding is in line with the knowledgebased view, which states that intellectual capital as an intangible capital that can create value and enhance innovation that will lead to organizational performance for SMEs Batik. Previous studies also supported the findings such as Delgado-Verde et al, [10], Supriyadi [12] and Khalique [5]. Managing intellectual capital becomes one of the most important issues especially for SMEs Batik.

For SMEs Batik, the role of intellectual capital in developing competitive advantage is enormous. Intellectual capital as an intangible asset is a valuable, inimitable and nonsubstitutable resource. The emphasis is more on human capital because human capital in SMEs Batik is very instrumental in organizational management. Human capital was the "spirit" for intellectual capital since it played an important role within the strategic planning in creating performance [18]. Human capital led to the "knowledge, ability and employee's experience" [19]. For SME's, human capital is the main function of intellectual capital, the knowledge embedded was investment to achieve the competitive advantage of SME's.

The suggestion for this study, that the manager had to improve the creativity and innovation related to the explore of intellectual capital. Because for SMEs this capital was the determinant factor who leads to performance improvement. The limitations, the result cannot be generalized because the sample just takes on one cluster of SMEs. For further research, it is necessary to need to expand the population and coverage. 


\section{References}

[1] J. Chen, Z. Zhu, and H. Y. Xie, "Measuring intellectual capital: a new model and empirical study," J. Intellect. Cap., 2004.

[2] F. Vazquez and M. Michalski, "The Importance of Intellectual Capital for the Entrepreneurial Firm." Akademin för hållbar samhälls-och teknikutveckling, 2008.

[3] N. Bontis, "Intellectual capital disclosure in Canadian corporations," J. Hum. Resour. Costing Account., vol. 7, no. 1/2, pp. 9-20, 2003.

[4] A. Daou, E. Karuranga, and Z. Su, "Intellectual capital in Mexican SMEs from the perspective of the resource-based and dynamic capabilities views," J. Appl. Bus. Res., vol. 29, no. 6, pp. 1673-1688, 2013.

[5] M. Khalique, N. Bontis, J. A. N. bin Shaari, and A. H. B. M. Isa, "Intellectual capital in small and medium enterprises in Pakistan," J. Intellect. Cap., vol. 16, no. 1, pp. 224-238, 2015.

[6] R. Ngah and A. R. Ibrahim, "The Relationship of Intellectual Capital , Innovation and Organizational Performance: a Preliminary Study in Malaysian SMEs," Int. J. Manag. Innov. Syst., vol. 1, no. 1, pp. 1-13, 2009.

[7] R. M. Grant, "Toward A Knowledge- Based Theory of the Firm," Strateg. Manag. J. ;, vol. 17, no. Winter Special, 1996

[8] M. D. R. Cabrita and N. Bontis, "Intellectual capital and business performance in the Portuguese banking industry," Int. J. Technol. Manag., vol. 43, no. 1, pp. 212-237, 2008.

[9] X. Wu and V. Sivalogathasan, "Innovation Capability for better Performance: Intellectual Capital and Organization Performance of the Apparel Industry in Sri Lanka," J. Adv. Manag. Sci., vol. 1, no. 3, pp. 273-277, 2013.

[10] M. Delgado-Verde, G. M. Castro, J. E. Navas López, and J. E. Navas-Lopez, "Organizational knowledge assets and innovation capability: Evidence from Spanish manufacturing firms," $J$. Intellect. Cap., vol. 12, no. 1, pp. 5-19, 2011.

[11] R. E. Supriyadi, "The Effect of Strategic Partnership On Innovation Capability and Business Performance Of Garment Industry In West Java - Indonesia," Int. J. Sci. Technol. Res. Vol., vol. 3, no. 12, 2014.

[12] E. Supriyadi, "Spss+ Amos," Jakarta: In Media, 2014

[13] L. Yuan, L. Zhou, G. Bruton, and W. Li, "Capabilities as a mediator linking international diversification and innovation performance of firms in an emerging economy," J. Bus. Res., vol. 69, no. 8, pp. 2678-2686, 2010.

[14] T. Newbold et al., "Testing the accuracy of species distribution models using species records from a new field survey," Oikos, vol. 119, no. 8, pp. 1326-1334, 2010.

[15] C. M. Jardon and M. S. Martos, "Intellectual capital as competitive advantage in emerging clusters in Latin America," J. Intellect. Cap., 2012.

[16] K. J. Hair, "Reciprocating machine." Google Patents, 17-Nov-1998.

[17] R. M. Baron and D. A. Kenny, "The moderator-mediator variable distinction in social psychological research: Conceptual, strategic, and statistical considerations.," J. Pers. Soc. Psychol., vol. 51, no. 6, p. 1173, 1986.

[18] L. Henry, "Intellectual capital in a recession : evidence from UK SMEs," J. Intellect. Cap., vol. 14, no. 1, pp. 84-101, 2013.

[19] N. Bontis and J. Fitz-enz, "Intellectual Capital ROI: A Causal Map Of Human Capital Antecedents And Consequents," J. Intellect. Cap., vol. 3, no. 3, pp. 223-247, 2002. 